\title{
Assessment of ecological status of street plantings in Lipetsk city
}

\author{
Elena Parakhina $^{1 *}$, Zhanna Silaeva $^{2}$, Ludmila Kiseleva $^{3}$, and Elena Zhidkova ${ }^{4}$ \\ ${ }^{1}$ Peoples' Friendship University of Russia (RUDN University), Faculty of Ecology, 6 Miklukho- \\ Maklaya St, Moscow, 117198, Russian Federation \\ ${ }^{2}$ Orel State Agrarian University named after N.V. Parakhina, Department of landscape architecture, \\ Orel, Russia \\ ${ }^{3}$ Orel State University named after I.S. Turgenev, Department of Plant Botany, Physiology and \\ Biochemistry, Orel, Russia \\ ${ }^{4}$ Lipetsk State Pedagogical University named after P.P. Semenov - Tyan-Shansky, Department of \\ Geography, Biology and Chemistry, Lipetsk, Russia
}

\begin{abstract}
The purpose of the work is to evaluate the ecological state of the prevailing species of woody plants in the city of Lipetsk and to elaborate recommendations for improving green spaces. There were examined thirty street landscaping facilities, including 8537 trees. In the course of the study, there were identified five classes of trees vitality. There were also calculated the average scores of the prevailing tree species and the overall ratio of the city street plantings. As a result of the study, there were identified 31 species of trees. $14.5 \%$ of the surveyed trees were classified as "healthy" by vital condition. The "weakened trees" group got $38.8 \%$. "Severely weakened" group counted $24.7 \%$. The category" shrinking" trees had $19.2 \%$. Completely dry woody plants scored $2.8 \%$. Based on the obtained data, there were made recommendations how to improve the sustainability of green spaces in an urbanized environment.
\end{abstract}

\section{Introduction}

Creating a comfortable urban environment is a priority in many cities of our country, since human health depends directly on the conditions in which they live. Increasing the comfort of a person's stay in the city conditions is possible through the preservation and development of the system of planting. An important component of the system of planting of any city is played by woody plants. In addition to aesthetic and sanitary and hygienic functions, wood plantations also play a recreational role.

However, at present the pressure on urbanized areas has increased due to the increasing influence of human economic activity, which reduces the comfort of the urban environment. In addition, the modern system of planting in most cities of the European part of Russia, including Lipetsk, was formed in the 60-70s years of the last century.

In the last decade, interest to the system of planting has been growing: the range of plants used is expanding, interesting landscape compositions (topiaries and arboplastics) are appearing, and modern technologies of care work are being developed.

\footnotetext{
*Corresponding author: parakhina-ea@rudn.ru
} 
In this regard, it becomes relevant to study the current state of urban tree vegetation in order to determine the degree of harmful anthropogenic impact, predict the fate of plantations and theoretical basis for conservation measures.

Many researchers are engaged in studying of a condition of woody plants in the conditions of the urbanized environment, increasing of its comfort, development of an ecological framework of cities with participation of woody plants, studying of anthropogenic influence on green plantations [1-4]. At the same time, only some authors are engaged in identifying the current state of plants and their degree of disturbance $[5,6]$. The state of plantations was assessed in small towns of the Lipetsk region [7, 8]. No such work was carried out in Lipetsk. Although the city is a major industrial center. There is a work " Otsenka..." [9], which addresses the impact of the urban environment on plants, but does not address the issues of plant vitality assessment in urbanization.

The purpose of our work is to assess the ecological condition of the prevailing species of woody plants in Lipetsk and to recommend improvements to green plantations for a comfortable environment.

\section{Research methods}

The vitality assessment of wood plantations was carried out in 2018-2019 using the method of the state of trees and forest stands diagnostic [10]. A total of 8,537 trees belonging to 31 species were examined. We calculated the average state score for each tree species (CI) and the total coefficient of the green plantings condition (Ctot.) in Lipetsk. It was established borders of wood plantations, determined the species and were determined scores status of individual trees of each species using the scale visual assessment of trees by their appearance (overall condition of the plants, density of leafy, the degree of stem and crown damage, etc.).

The trees examined were part of thirty public plantations: planting strips along the main streets, including areas in the citywide shopping and administrative centers of Lipetsk. A total of 30 streets were investigated.

\section{Results and discussion}

Lipetsk is one of the largest cities in the Central Chernozemic region of Russia, the agglomeration center, where the production of full-cycle iron industry is concentrated. It is the city-resort. It was founded in 1703, although the first settlements on this territory date back to the II Millennium BC. Initially, Lipetsk was founded around iron factories during the reign of Peter I and only in 1779, by decree of Empress Catherine II, it received the status of a district city of the Tambov province. Lipetsk became the center of the Lipetsk region in 1954 [9].

During the Great Patriotic War (1941-1945), the city's wood plantations did not suffer much. Many trees and shrubs have been preserved. For example, there is an oak grove in the Verhniy Park with trees more than 200 years old.

In the following years, about 30 species of tree and shrub species were used in city landscape construction, mostly wild, for example, Quercus robur L., Tilia cordata Mill., Acer platanoides L. and others, as well as the most widely distributed introducers - Acer negundo L., Caragana arborescens Lam., Larix sibirica Ledeb. etc. This is typical of many cities [5, 6].

When assessing the of woody plants condition in Lipetsk, it was found that trees predominate in green plantations, which create a favorable environment for human health. This is why we first assessed the sustainability of trees. Most often, 31 species of trees are found in Lipetsk (table 1). 
Table 1. Average points (Ki) of state of tree species and total state coefficient (Kt) of studied green plantations in Lipetsk

\begin{tabular}{|c|c|c|c|}
\hline № & Species & $\mathbf{K i}$ & Kt \\
\hline 1 & Acer negundo L. & 2.78 & \multirow{31}{*}{2.01} \\
\hline 2 & Acer platanoides $\mathrm{L}$. & 1.91 & \\
\hline 3 & Acer saccharum Marshall & 2.31 & \\
\hline 4 & Aesculus hippocastanum L. & 2.45 & \\
\hline 5 & Betula pendula Roth. & 1.76 & \\
\hline 6 & Caragana arborescens Lam. & 2.86 & \\
\hline 7 & Crataegus submollis Sarg. & 1.32 & \\
\hline 8 & Fraxinus excelsior $\mathrm{L}$. & 2.89 & \\
\hline 9 & Fraxinus pennsylvanica March. & 2.33 & \\
\hline 10 & Larix sibirica Ledeb. & 2.44 & \\
\hline 11 & Malus domestica Borkh. & 2.86 & \\
\hline 12 & Picea abies (L.) Karst. & 2.49 & \\
\hline 13 & Picea pungen Engelm. & 1.47 & \\
\hline 14 & Populus balsamifera $\mathrm{L}$. & 2.14 & \\
\hline 15 & Populus $\times$ berolinensis $($ C. Koch) Dipp. & 2.56 & \\
\hline 16 & Populus nigra $\mathrm{L}$. & 1.89 & \\
\hline 17 & Populus tremula $\mathrm{L}$. & 1.47 & \\
\hline 18 & Pseudotsuga menziesii (Mirb.) Franco & 2.14 & \\
\hline 19 & Quercus robur $\mathrm{L}$. & 1.66 & \\
\hline 20 & Robinia pseudoacacia L. & 2.35 & \\
\hline 21 & Salix alba L. & 1.81 & \\
\hline 22 & Salix babylonica $\mathrm{L}$. & 1.72 & \\
\hline 23 & Salix caprea $\mathrm{L}$. & 1.03 & \\
\hline 24 & Salix fragilis $\mathrm{L}$. & 1.58 & \\
\hline 25 & Sorbus aucuparia $\mathrm{L}$. & 2.56 & \\
\hline 26 & Thuja occidentalis L. & 3.04 & \\
\hline 27 & Tilia cordata Mill. & 1.78 & \\
\hline 28 & Tilia platyphyllos Scop. & 1.63 & \\
\hline 29 & Ulmus glabra Huds. & 2.93 & \\
\hline 30 & Ulmus laevis Pall. & 2.74 & \\
\hline 31 & Ulmus pumila $\mathrm{L}$. & 2.15 & \\
\hline
\end{tabular}

Currently, the average trees age in the city is 50-70 years.

During the work, a visual condition assessment of 8537 trees growing on 30 streets of the city was carried out and 5 vitality classes were identified (Fig.1).

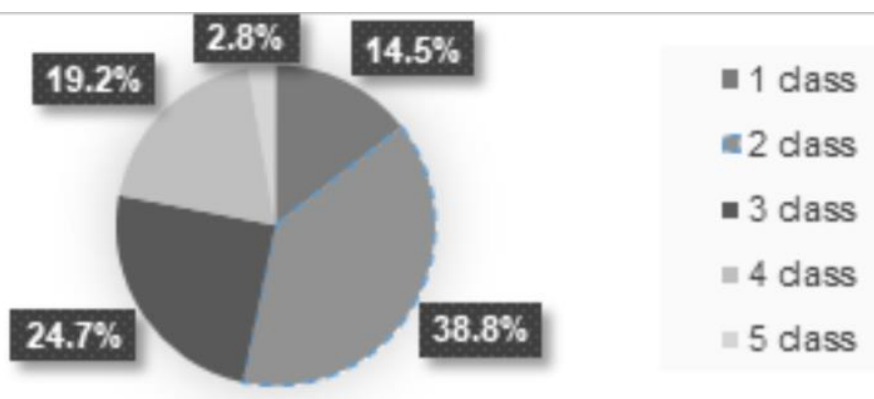

Fig. 1. Percentage distribution of the studied trees in Lipetsk by vitality classes ( 1 class - healthy, 2 class - weakened, 3 class - severely weakened, 4 class - shrinking, 5 class - dry). 
Only $1238(14.5 \%)$ of the examined trees are classified as "healthy". $3312(38.8 \%)$ trees refer to the "weak trees" class. They have minor damage: shrinking branches, thinning crown, possibly the presence of ectoparasites.

"Severely weakened" trees account for 2109 trees (24.7\%). This category is characterized by significant shrinking of branches, dryness, boundary and central chlorosis, and in some places there is the bark dying off.

The category" shrinking " includes -1639 trees (19.2\%). There is a shrinking of branches throughout the crown, there is no growth, and there are numerous bodies of marsupials and basidial fungi on the trunks.

Woody plants that are completely dry (without leaves, the bark is peeling or completely absent) are 239 trees $(2.8 \%$ ). It should be noted that this class includes mainly representatives of the genus Populus L. (Populus nigra L., represented in the Lipetsk plantations mainly pyramidal form, $P . \times$ berolinensis (C. Koch) Dipp. etc.).

Based on the results of calculating the average state score for each species of tree and the overall state coefficient of green plantations, it was found that the tree plantations of Lipetsk streets are weakened $(\mathrm{C}$ tot. $=62.35 / 31=2.01)$ requiring preventive measures, pruning and sanitation (table.1).

The research also noted that low vitality is observed in species that grow along main streets with heavy traffic. Plants of the following species were most affected: Betula pendula Roth, Fraxinus excelsior L., Acer platanoides L., Populus nigra L., Acer negundo L., Caragana arborescens Lam.

The main reasons for mass drying, thinning, and dying of trees in the city's plantations are: compaction and salinization of the soil, lack of proper agricultural equipment, and mechanical damage. As a result, vulnerability to pests and diseases increases. The following diseases are most common on trees and shrubs in Lipetsk: necrotic-cancerous on branches and trunks, vascular diseases, leaf spots, rust, powdery mildew, rotten diseases, etc. A similar situation is noted in another Russian cities $[1,2,3,4,6]$.

The system of increasing the sustainability of woody plants and protecting plantationss in the city should include a set of measures. The main ones are: organization of general supervision over the appearance and spread of pests and diseases; quarantine measures and certification of planting material; preventive activities aimed at increasing the plants resistance to negative factors of the urban environment; measures for active plants protection from pests and diseases [6].

It should be noted that in recent years, various measures have been carried out in Lipetsk to improve the urban environment and replace plantatons. In the future, this will have a positive impact on the urban environment state, increase its comfort, and, consequently, it will have a positive impact on human health.

\section{Conclusions}

Thus, according to the results of the study, the following conclusions can be drawn:

1. The species composition of tree plants in Lipetsk, used in landscaping street plantings in Lipetsk, is represented by 31 species of trees, with the predominant native species: Quercus robur L., Tilia cordata Mill., Acer platanoides L.

2. The result of the visual evaluation 8537 trees growing on 30 city streets found that: $14,5 \%$ of the surveyed trees are classified as "healthy"; the share of damaged trees accounted for $38.8 \%$; the category of "severely weakened" trees is $24.7 \%$ of the trees, and "drying" is $19.2 \%$; woody plants completely dry $2.8 \%$ of the studied breeds. 
3. Based on the results of calculating the average state score for each type of tree and the overall coefficient of the state of green spaces, it was found that the tree stands of the streets of Lipetsk are weakened, requiring preventive measures, pruning and sanitation.

4. Based on the obtained data, the following recommendations are proposed: organization of General supervision over the appearance and spread of pests and diseases; quarantine measures and certification of planting material; preventive activities aimed at increasing the resistance of plants to negative factors of the urban environment; measures for active protection of plants from pests and diseases.

\section{References}

1. I.L. Bukharina, Izv. Samarsk. nauch. tsentra RAN, 10, 607-612 (2008) (in Russian).

2. M.V. Larionov, N.V. Larionov, T.S. Gromova, I.S. Sirayeva, E.A. Logacheva, V.V. Soldatova, Aktualnye problemy prirodopol'zovaniya i prirodoobustrojstva, 179-184 (2019) (in Russian).

3. N.B. Prokhorenko, G.V. Demina, Izv. Samarsk. nauch. tsentra RAN, 18, 177-181 (2016) (in Russian).

4. A.K. Razinkova, E.N. Perelygina, Lesotekh. Zh, 6, 36-46 (2016) (in Russian).

5. E.A Deynega, Dendroflora g. Dubna Moskovskoj oblasti: raznoobrazie i zhiznennoe sostoyanie zelenyh nasazhdenij, (2016) (in Russian).

6. L.L. Kiseleva, E.A. Parahina, Zh.G. Silayeva, Izv. Samarskogo nauch. tsentra RAN, 18, 702-706 (2016) (in Russian).

7. O.G. Bolysheva, Ocenka sostoyaniya nasazhdenij i napravleniya optimizacii ozeleneniya malyh gorodov Lipeckoj oblasti, (2013) (in Russian).

8. I.L. Bukharina, A.N. Zhuravleva, O.G. Bolysheva Gorodskie nasazhdeniya: ekologicheskij aspect (2012) (in Russian).

9. Otsenka zelenykh nasazhdeniy goroda Lipetska. URL: http://www.hintfox.com/article/otsenka-zelenih-nasazhdenij-goroda-lipetska.html (in Russian).

10. V.A. Alekseyev, Lesovedeniye, 4, 51-57 (1989) (in Russian). 